\title{
Adenosylcobalamin-dependent methylmalonyl- CoA mutase isozymes in the photosynthetic protozoon Euglena gracilis Z
}

\author{
Fumio Watanabe, ${ }^{1}$ Katsuo Abe, ${ }^{1}$ Yoshiyuki Tamura ${ }^{2}$ \\ and Yoshihisa Nakano ${ }^{3}$
}

1 Department of Food and Nutrition, Kochi Women's University, Kochi 780 , Japan

2 Laboratory of Nutrition and Food Science, Hagoromo-gakuen College, Sakai, Osaka 592. Japan

3 Department of Applied Biological Chemistry. Osaka Prefecture University, Sakai, Osaka 593, Japan

\author{
Author for correspondence: Fumio Watanabe. Tel/Fax: +81 888312876. \\ e-mail: watanabe(a)cc.kochi-wu.ac.jp
}

Keywords: propionate metabolism, adenosylcobalamin, methylmalonyl-CoA mutase, mitochondria, Euglena gracilis $\mathrm{Z}$

\section{INTRODUCTION}

Euglena gracilis Z, a photosynthetic flagellate, combines characteristics of both plant and animal cells (Kitaoka et al., 1989). E. gracilis $Z$ requires cobalamin $(\mathrm{Cbl})$ for growth (Watanabe et al., 1992). It can take up and accumulate $\mathrm{Cbl}$, which is converted into coenzymes $5^{\prime}$ deoxyadenosylcobalamin (AdoCbl) and methylcobalamin (Isegawa et al., 1984). Cbl uptake by Euglena mitochondria is shown to be a biphasic process, consisting of energyindependent Cbl-binding to the mitochondrial membrane and energy-dependent active transport (Watanabe et al., 1993a). The enzymes involved in the synthesis of AdoCbl are found only in the mitochondria (Watanabe et al., 1987a). AdoCbl synthesized in the mitochondtia is the cofactor of ribonucleotide reductase (EC 1.17.4.2), which functions in DNA synthesis (Hamilton, 1974). Euglena cells also contain methylcobalamin-dependent methionine synthase (EC 2.1.1.13) isozymes, which are located in the cytosol, chloroplasts and mitochondria (Isegawa et al., 1994). The isozymes supply methionine for protein synthesis in the individual organelles.

Numerous non-enzymic Cbl-binding proteins are distributed in the mitochondria, microsomes, chloroplasts,

Abbreviations: AdoCbl, 5 -deoxyadenosylcobalamin; $\mathrm{Cbl}$, cobalamin: MCM, methylmalonyl-CoA mutase. cytosol, pellicle and culture broth of E. gracilis Z. Some of them have been purified and characterized (Watanabe $e t$ al., 1987b, c, 1988a, b). The Cbl-binding protein has an absolute requirement for the complete Cbl molecule with an $\alpha$-axial ligand (the cobalt-coordinated nucleotide) and an intact $b$-propionamide side-chain (Watanabe et al., $1993 \mathrm{a}, \mathrm{b}, \mathrm{c})$. Thus, E. gracilis $\mathrm{Z}$ is suitable for elucidating physiological roles of $\mathrm{Cbl}$ in photosynthetic microorganisms.

E. gracilis $\mathrm{Z}$ can utilize propionate for growth as sole carbon source only under illumination, being converted into cell components through the methylmalonyl-CoA mutase (MCM; EC 5.4.99.2) pathway (Yokota et al., 1982). This pathway metabolizes odd-chain fatty acids and branched-chain amino acids to methylmalonyl-CoA, which is converted to the Krebs cycle intermediate succinyl-CoA by MCM (Rosenberg \& Fenton, 1989). There is little information available on the enzymological properties of the AdoCbl-dependent MCM in E. gracilis $Z$. Here we describe the occurrence and subcellular location of MCM isozymes and attempt to clarify propionate metabolism in this protozoon.

\section{METHODS}

Culture and organism. E. gracilis $\mathrm{Z}$ was photoautotrophically cultured for $12 \mathrm{~d}$ at $27^{\circ} \mathrm{C}$ with illumination $(8000 \mathrm{~lx})$ in Cramer-Myers medium (Cramer \& Myers, 1952) containing 
cyanocobalamin $\left(5 \mu \mathrm{g} \mathrm{l}^{-\mathbf{1}}\right)$. This autotrophic medium was supplemented with $6.6 \mathrm{~g}$, propionate $\mathrm{l}^{-1}$ and the cells were subcultured several times $(>5)$ under the same conditions to adapt them to propionate.

Crude enzyme preparation. Propionate-adapted and photoautotrophic Euglena cells were grown for $12 \mathrm{~d}$ at $27^{\circ} \mathrm{C}$ with illumination in the Cramer-Myers medium with and without propionate $\left(6.6 \mathrm{~g} \mathrm{l}^{-1}\right)$, respectively. The cells were washed twice with distilled water, suspended in $20 \mathrm{ml} 10 \mathrm{mM}$ potassium phosphate buffer, $\mathrm{pH} 7 \cdot 0$, containing $1 \mathrm{mM}$ EDTA, distupted by sonication $(10 \mathrm{kHz}, 20 \mathrm{~s} \times 4)$, and centrifuged at $20000 \mathrm{~g}$ for $30 \mathrm{~min}$. The supernatant fraction was used as a crude enzyme.

Enzyme assay. MCM was spectrophotometrically assayed (Hitachi 200-10 spectrophotometer) by the succinylCoA transferase/ $\beta$-hydroxyacyl-CoA-dehydrogenase-coupled method (Watanabe et al., 1993d). Briefly, the assay mixture $(0.5 \mathrm{ml})$ contained $10 \mathrm{mM}$ potassium phosphate buffer, $\mathrm{pH} 7.0$, $10 \mu \mathrm{M}$ AdoCbl, $0.5 \mathrm{mM}$ DL-methylmalonyl-Co A, $5 \mathrm{mM}$ lithium acetoacetate, $0.15 \mathrm{mM}$ NADH, 0.1 unit succinyl-CoA transferase, 1.5 unit $\beta$-hydroxyacyl-CoA dehydrogenase and crude enzyme. The components, except for DL-methylmalonyl-CoA, were mixed in a $0.7 \mathrm{ml}$ cuvette, and the temperature was equilibrated by incubation in a water-jacketed cuvette holder maintained at $30^{\circ} \mathrm{C}$. The reaction was started by addition of $\mathrm{DL}-$ methylmalonyl-CoA. MCM activity was calculated from the decrease in NADH concentration, measured by the change in $A_{340}$. The activity of apo-MCM was calculated by subtracting activity in the absence of AdoCbl from that in the presence of AdoCbl. Results are expressed as nmol succinate formed $\mathrm{min}^{-1}$ (mg protein) $)^{-1} \pm \mathrm{SD}$ of triplicate experiments.

Subcellular fractionation. Propionate-adapted cells were centrifuged at $2000 \mathrm{~g}$ for $10 \mathrm{~min}$ and washed twice with distilled water. The cells (31 g wet weight) were suspended in $50 \mathrm{ml}$ $25 \mathrm{mM}$ HEPES/KOH buffer, $\mathrm{pH} 7 \cdot 0$, containing $0.33 \mathrm{M}$ mannitol and then disrupted by gently grinding with $30-40$-mesh sea sand $(5 \mathrm{~g})$ for $10 \mathrm{~min}$ using a mortar and pestle. The suspension was filtered through a double layer of gauze to remove the sand and then centrifuged at $2000 \mathrm{~g}$ for $10 \mathrm{~min}$ to remove unbroken cells. The supernatant was subjected to differential centrifugation according to Tokunaga et al. (1979).

The following marker enzyme activities were assayed by the methods described in the cited references: glutamate dehydrogenase (EC 1.4.1.2; Tokunaga et al., 1979), a marker enzyme of Euglena cytosol; succinate-semialdehyde dehydrogenase (EC 1.2.1.16; Tokunaga et al., 1976), a marker enzyme of the mitochondrial matrix; ribulose-bisphosphate carboxylase/ oxygenase (EC 4.1.1.39; Rabinowitz et al., 1975), a marker enzyme of chloroplasts; and glucose-6-phosphatase (EC 3.1.3.9; de Duve et al., 1955), a marker enzyme of microsomes.

The mitochondria and chloroplasts were further purified by a Percoll density gradient centrifugation (Watanabe et al., 1987b; Isegawa $e t$ al., 1984), and suspended in $2.0 \mathrm{ml} 10 \mathrm{mM}$ potassium phosphate buffer, $\mathrm{pH} 7 \cdot 0$, containing $100 \mathrm{mM}$ potassium chloride and $1 \mathrm{mMEDTA}$. These organelles were disrupted by sonication $(10 \mathrm{kHz}, 10 \mathrm{~s} \times 5)$ and used as samples for Toyopeatl HW55S gel-filtration experiments.

Gel-filtration experiments. The $M_{\mathrm{r}}$ of the Euglena MCM was determined by HPLC (Shimadzu LC-7A pump and SPD-7AV spectrophotometer, and a Hitachi Chromato-data processor D2500 ) using a Toyopearl HW55S column $(1 \cdot 0 \times 28.5 \mathrm{~cm})$. The column was equilibrated with $10 \mathrm{mM}$ potassium phosphate buffer, $\mathrm{pH} 7.0$, containing $100 \mathrm{mM}$ potassium chloride and
$1 \mathrm{mM}$ EDTA and eluted with the same buffer at a flow rate of $0.5 \mathrm{ml} \mathrm{min}^{-1}$. The column was calibrated with blue dextran (mean $M_{\mathrm{r}} 2000000$ ), yeast alcohol dehydrogenase $\left(M_{\mathrm{r}} 150000\right)$, bovine serum albumin $\left(M_{r} 66000\right)$, ovalbumin $\left(M_{\mathrm{r}} 45000\right)$ and soybean trypsin inhibitor $\left(M_{\mathrm{r}} 20000\right)$. Blue dextran was assayed by measuring the $A_{650}$. The enzymes and proteins wete monitored by measuring the $A_{280}$.

Protein assay. Protein was assayed by the method of Bradford (1976), with ovalbumin as standard.

Materials. DL-Methylmalonyl-CoA, succinyl-CoA transferase, $\beta$-hydroxyacyl-CoA dehydrogenase and AdoCbl were obtained from Sigma. Toyopearl HW55S was obtained from Tosoh.

\section{RESULTS AND DISCUSSION}

\section{Occurrence of MCM in E. gracilis Z}

MCM activity was found in homogenates of Euglena cells grown photoautotrophically (control) or adapted to the propionate-supplemented medium. The specific activity of total MCM (both holo- and apoenzymes) was about 6.5-fold higher in the propionate-adapted cells than in the control cells $\left[17.41 \pm 2.87\right.$ and $2.64 \pm 0.13 \mathrm{nmol} \mathrm{min}^{-1}$ (mg protein $)^{-1}$, respectively], and was similar to that of human liver MCM $\left[24 \mathrm{nmol} \mathrm{min}^{-1}(\mathrm{mg} \text { protein })^{-1}\right.$ : Fenton et al., 1982). In the absence of AdoCbl, the MCM activity of the propionate-adapted cells decreased to about $50 \%$ of the activity $\left[7.97 \pm 7.35 \mathrm{nmol} \mathrm{min}{ }^{-1}\right.$ (mg protein $\left.)^{-1}\right]$ and the control only changed slightly $[2 \cdot 42 \pm$ $0.11 \mathrm{nmol} \mathrm{min}^{-1}$ (mg protein) $)^{-1}$, indicating that half of the activity of the MCM detected had bound AdoCbl as the cofactor. Only residual activity $\left[<0.1 \mathrm{nmol} \mathrm{min}{ }^{-1}\right.$ (mg protein) ${ }^{-1}$ ] of MCM was found in a cell homogenate of E. gracilis Z grown heterotrophically in Koren-Hutner medium (Koren \& Hutner, 1967). Increased MCM activity in propionate-adapted cells is therefore due to induction of the MCM enzyme by propionate photoassimilation.

\section{Subcellular distribution of MCM}

Fig. 1 shows activities of MCM and marker enzymes in the subcellular fractions from differential centrifugation of an homogenate of the propionate-adapted E. gracilis Z. The enzyme activities were plotted as relative specific activity in each fraction versus percentage protein (Beaufay et al., 1964). Based upon the distribution of the marker enzymes succinate-semialdehyde dehydrogenase (mitochondria), ribulose-bisphosphate carboxylase/oxygenase (chloroplasts), glucose-6-phosphatase (microsomes) and glutamate dehydrogenase (cytosol), these organelles were separated satisfactorily. MCM activity was predominantly located in the mitochondrial fraction (Fig. 1), which also had the highest specific activity $\left[172.8 \mathrm{nmol} \mathrm{min}{ }^{-1}\right.$ (mg protein $\left.)^{-1}\right]$. When the mitochondrial and chloroplast fractions were purified by Percoll density gradient centrifugation, the specific activity of MCM increased about twofold in the Percoll-purified mitochondrial fraction [354.6 nmol min ${ }^{-1}$ (mg protein) $)^{-1}$ ], while the chloroplast MCM activity disappeared. The MCM activity in the microsomal fraction was due to contamination by the 


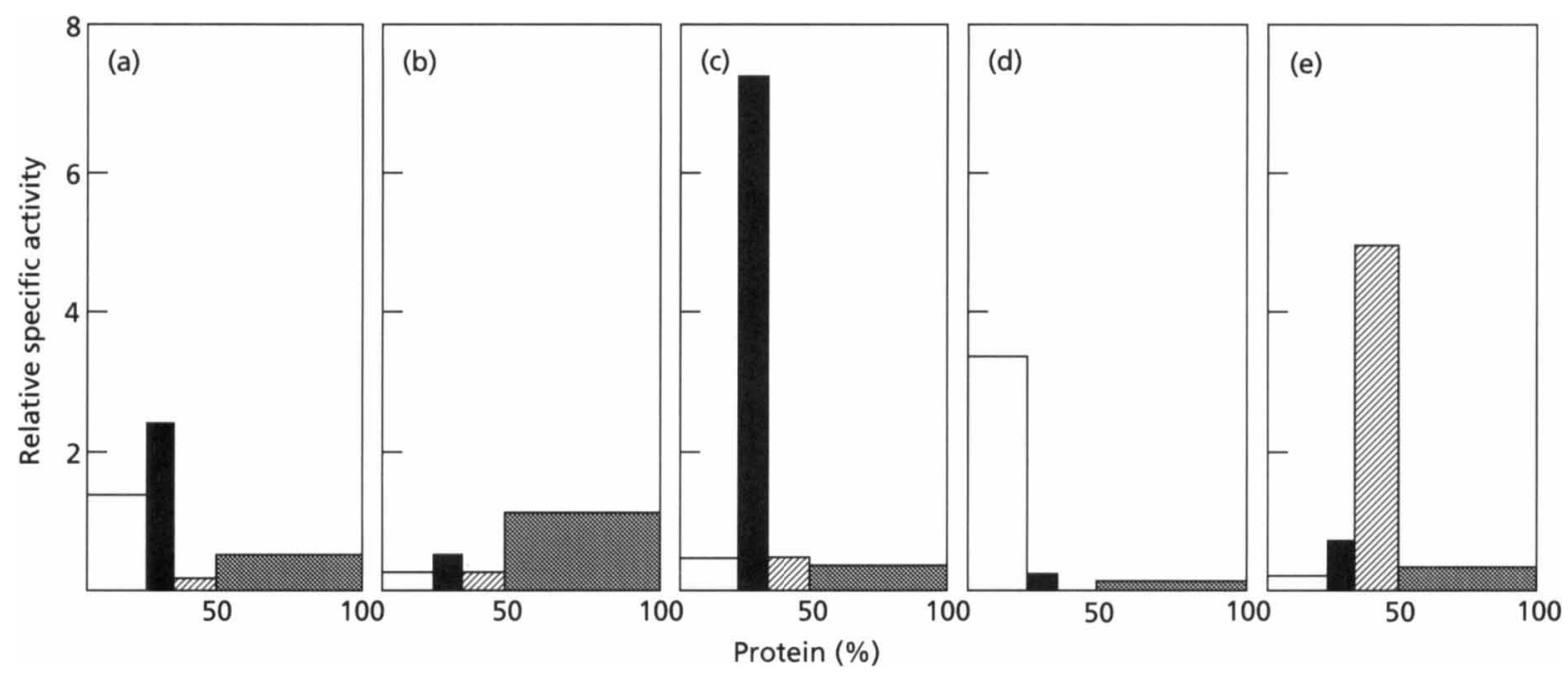

Fig. 1. Subcellular localization of MCM in propionate-adapted Euglena cells. The procedures for subcellular fractionation and assay of MCM and marker enzymes are described in Methods. The distribution pattern is typical of that obtained in three separate experiments. Homogenates of Euglena cells were subjected to differential centrifugation, with increasing $g$ force from left to right. $\square$, Chloroplast fraction; $\boldsymbol{Q}$, mitochondrial fraction; $\mathbb{Z}$, microsomal fraction; . fraction. MCM and marker enzymes are plotted as relative specific activity in each fraction versus percentage protein. Recoveries were $103 \%$ for MCM (a), $101 \%$ for glutamate dehydrogenase (b; cytosolic marker enzyme), 101\% for succinate-semialdehyde dehydrogenase ( $c_{\text {; }}$ mitochondrial marker enzyme), $103 \%$ for ribulose-bisphosphate carboxylase/oxygenase (d; chloroplastic marker enzyme), $103 \%$ for glucose-6-phosphatase (e; microsomal marker enzyme) and $104 \%$ for protein.

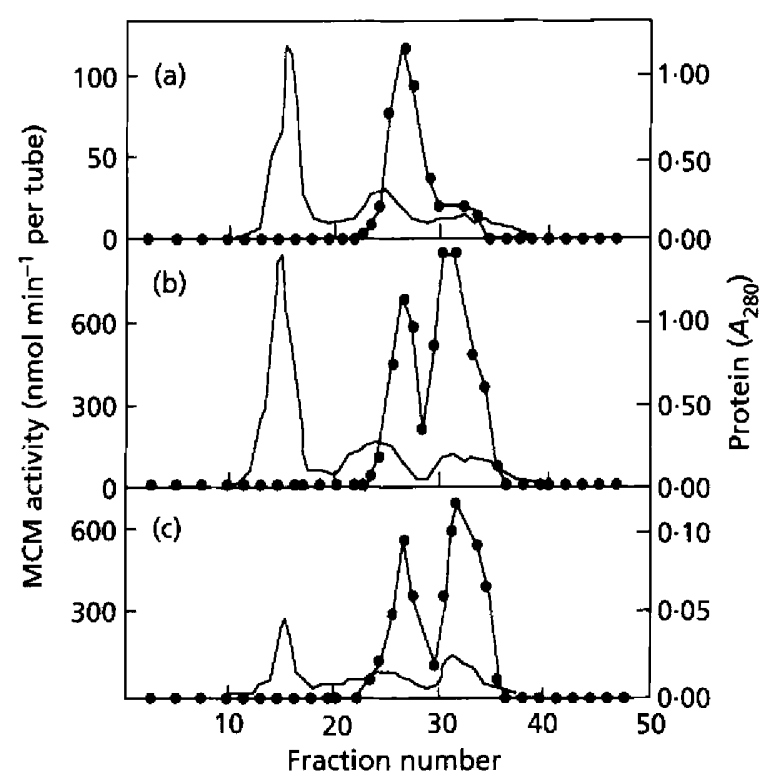

Fig. 2. Elution patterns of Euglena MCM on Toyopearl HW555 column chromatography. MCM activity was separated and assayed as described in Methods. The data are from a run of four separate experiments. (a) Crude homogenate from photoautotrophic Euglena cells (control); (b) crude homogenate from propionate-adapted cells; (c) mitochondrial fraction from the propionate-adapted cells. Solid line, protein; - MCM activity.

cytosolic fraction since washing the fraction with $10 \mathrm{mM}$ HEPES/KOH buffer, $\mathrm{pH} 7 \cdot 0$, containing $0 \cdot 25 \mathrm{M}$ sucrose removed the activity. The cytosolic MCM activity was also due to contamination of the soluble fraction by damaged mitochondria since a minor amount of succinatesemialdehyde dehydrogenase, a mitochondrial marker enzyme, was also recovered in the cytosolic fraction. These results indicate that Euglena MCM is enriched in the mitochondrial fraction; it is identical in subcellulat location to the mammalian MCM (Rosenberg \& Fenton, 1989).

\section{MCM isozymes}

Fig. 2(a, b) shows the elution profile of MCM activity in control and propionate-adapted Euglena cells during Toyopearl HW55S gel filtration. The MCM activity of control cells eluted as a peak with an apparent $M_{\mathrm{r}}$ of 72000 , while that of the propionate-adapted cells eluted as two peaks with apparent $M_{\mathrm{r}}$ values of 72000 and 17000 ; an identical elution profile for the MCM activity of the mitochondria fractionated from the propionate-adapted cells was obtained (Fig. 2c). These results indicate that the mitochondria of the propionate-adapted Euglena cells contain the two MCM isozymes with apparent $M_{\mathbf{r}}$ values of 72000 (large MCM) and 17000 (small MCM), and that the large and small MCMs are constitutive and inducible enzymes, respectively.

The enzyme has been isolated from human (Fenton et al., 1982) and sheep (Cannata et al., 1965) livers and from Propionibacterium shermanii (Francalanci et al., 1986). The human enzyme consists of a homodimer (identical subunits with $M_{\mathrm{r}}$ values of $72000-77500$ ), while the bacterial enzyme consists of two non-identical subunits with $M_{\mathrm{r}}$ values of 79000 and 67000 . The human MCM contains $2 \mathrm{~mol}$ AdoCbl (mol enzyme) ${ }^{-1}$. The AdoCbl content of 
the bacterial enzyme has not been reported because the enzyme is purified as an apoenzyme. Sheep-liver MCM is sensitive to thiol reagents such as $N$-ethylmaleimide, which has no effect on the activity of the bacterial enzyme. Kinetic properties of the mammalian and bacterial enzymes also differ.

The Euglena large MCM had a similar $M_{\mathrm{r}}$ to the mammalian and bacterial subunits. The Euglena small MCM possibly has the smallest $M_{\mathrm{r}}$ among the Cbldependent enzymes which have been reported. In this paper, we have demonstrated the first occurrence of the propionate-induced small MCM in organisms.

The results presented here provide evidence that the propionate-adapted Euglena cells contain the two MCM isozymes. The small MCM is induced significantly, presumably to enable photoassimilation of propionate.

\section{ACKNOWLEDGEMENTS}

This study was supported in part by a research fund of the Japanese Private School foundation (F.W. and Y.T.).

\section{REFERENCES}

Beaufay, H., Jacques, P., Baudhuin, P., Sellinger, O. Z., Berthet, J. $\&$ de Duve, C. (1964). Resolution of mitochondrial fractions from rat liver into three distinct populations of cytoplasmic particles by means of density equilibration in various gradients. Biochem $J$ 92, 184-205.

Bradford, M. M. (1976). A rapid and sensitive method for the quantitation of microgram quantities of protein using the principle of protein-dye binding. Anal Biocbem 72, 248-254.

Cannata, J. J. B., Focesi, A.r Jr, Mazumder, R., Warner, R. C. \& Ochoa, S. (1965). Metabolism of propionic acid in animal tissues. XII. Properties of mammalian methylmalonyl coenzyme A mutase. $J$ Biol Chem 240, 3249-3257.

Cramer, M. C. \& Myers, J. (1952). Growth and photosynthetic characteristics of Euglena gracilis. Arch Mikrobiol 17, 384-402.

de Duve, D., Pressman, B. C., Glanetto, R., Wattlaux, T. G. \& Applemans, F. (1955). Tissue fractionation studies. 6. Intracellular distribution patterns of enzymes in rat liver. Biochem J 60, 604-617.

Fenton, W. A., Hack, A. M., Willard, M. F., Gertler, A. \& Rosenberg, L. E. (1982). Purification and properties of methylmalonyl coenzyme A mutase from human liver. Arch Biochem Biopbys 214, 815-823.

Francalanci, F., Davis, N. K., Fuller, J. Q., Murfitt, D. \& Leadlay, P. F. (1986). The subunit structure of methylmalonyl-CoA mutase from Propionibacterium shermanii. Biochem J 236, 489-494.

Hamilton, F. D. (1974). Ribonucleotide reductase from Euglena gracilis: a 5'-deoxyadenosylcobalamin-dependent enzyme. $J$ Biol Chem 249, 4428-4434.

Isegawa, Y., Nakano, Y. \& Kitaoka, S. (1984). Conversion and distribution of cobalamin in Euglena gracilis $z$, with special reference to its location and probable function within chloroplasts. Plant Pbysiol 76, 814-818.

Isegawa, Y., Watanabe, F., Kitaoka, S. \& Nakano, Y. (1994). Subcellular distribution of cobalamin-dependent methionine synthase in Euglena gracilis z. Pbytochemistry 35, 59-61.
Kitaoka, S., Nakano, Y., Miyatake, K. \& Yokota, A. (1989). Enzymes and their functional location. In The Biology of Euglena, vol. 4, pp. 1-135. Edited by D. E. Buetow. San Diego: Academic Press. Koren, L. E. \& Hutner, S. H. (1967). High-yield media for photosynthesizing Euglena gracilis z. J Protozool 14S, 17.

Rabinowitz, H., Reisfeld, A., Sagher, D. \& Edelman, M. (1975). Ribulose diphosphate carboxylase from autotrophic Euglena gracilis. Plant Pbysiol 56, 345-350.

Rosenberg, L. E. \& Fenton, W. A. (1989). Disorders of propionate and methylmalonate metabolism. In The Metabolic Basis of Inherited Disease, pp. 822-844. Edited by C. R. Scriver, A. L. Beaudet, W. S. Sly \& D. Valle. New York: McGraw Hill.

Tokunaga, M., Nakano, Y. \& Kitaoka, S. (1976). Separation and properties of the NAD-linked and NADP-linked isozymes of succinic semialdehyde dehydrogenase in Exglena gracilis z. Biochim Biopbys Acta 429, 55-62.

Tokunaga, M., Nakano, Y. \& Kitaoka, S. (1979). Subcellular location of the GABA-shunt enzymes in Euglena gracilis strain Z.J Protozool 26, 471-473.

Watanabe, F., Nakano, Y. \& Kitaoka, S. (1987a). Purification and chatacterization of aquacobalamin reductase (NADPH) from Euglena gracilis. J Biol Cbem 262, 11514-11518.

Watanabe, F., Nakano, Y. \& Kitaoka, S. (1987b). Isolation and some properties of soluble and membrane-bound cobalamin binding proteins of Euglena mitochondria. Arch Microbiol 149, $30-35$.

Watanabe, F., Nakano, Y. \& Kitaoka, S. (1987c). Purification and some properties of cytosolic cobalamin-binding protein in Euglena gracilis. Biochem J 247, 679-685.

Watanabe, F., Ito, T., Tabuchi, T., Nakano, Y. \& Kitaoka, S. (1988a). Isolation of pellicular cobalamin-binding proteins of the cobalamin uptake system of Euglena gracilis. J Gen Microbiol 134, $67-74$.

Watanabe, F., Nakano, Y., Ochi, H. \& Kitaoka, S. (1988b). Purification, some properties and possible physiological role of an extracellular cobalamin binding protein from Euglena gracilis. I Gen Microbiol 134, 1385-1389.

Watanabe, F., Nakano, Y. \& Stupperich, E. (1992). Different corrinoid specificities for cell growth and the cobalamin uptake system in Euglena gracilis z. J Gen Microbiol 138, 1807-1813.

Watanabe, F., Nakano, Y. \& Stupperich, E. (1993a). Uptake of cobalamin by Exglena mitochondria. J Biochem 114, 793-799.

Watanabe, F., Nakano, Y., Tamura, T. \& Stupperich, E. (1993b). Corrinoid specificity of cytosolic cobalamin-binding protein of Euglena gracilis z. J Biocbem 113, 97-100.

Watanabe, F., Nakano, Y., Stupperich, E., Ushikoshi, K., Ushikoshi, S., Ushikoshi, I. \& Kitaoka, S. (1993c). A radioisotope dilution method for quantitation of total vitamin $\mathrm{B}_{12}$ in biological sample using isolated Euglena pellicle fragments as a solid-phase vitamin $\mathrm{B}_{12}$-binding material. Anal Chem 65, 657-659.

Watanabe, F., Tamura, Y., Saido, H. \& Nakano, Y. (1993d). Enzymatic assay for adenosylcobalamin-dependent methylmalonyl coenzyme A mutase. Biosci Biotechnol Biocbem 57, 1593-1594.

Yokota, A., Hosotani, K. \& Kitaoka, 5. (1982). Mechanism of metabolic regulation in photoassimilation of propionate in Euglena gracilis z. Arch Biocbem Biopbys 249, 530-537.

Received 17 November 1995; revised 1 March 1996; accepted 26 April 1996. 